DOI 10.23947/2414-1143-2020-24-4-82-89

UDC $94(470) \ll 1853 / 1856 »$

\title{
CRIMEAN WAR: MEDICAL AND SOCIAL CHARACTERISTICS AND CONSEQUENCES
}

\author{
(C) Elena K. Sklyarova, Olga N. Kamalova
}

\author{
Rostov State Medical University. Rostov-on-Don, Russian Federation \\ science-almanac@mail.ru
}

The medical and social features and consequences of the Crimean War (1853 - 1856) are considered. Based on the historical and genetic research method, the author analyzes the process of creating an army health system, the problem of corruption in the context of the history of Great Britain, the Ottoman and Russian empires in the middle of the 19th century. Public health, nursing training, and army health care became a new field of medicine. The consequence of the Crimean War was the formation of women's medical activities, the organization of state care for the wounded, the elimination of corruption in the army, which were carried out in the Crimean hospitals (in Sevastopol, Bakhchisarai, Karasu-Bazar, Kozlov, Simferopol), in Turkish hospitals (in Scutari, Renkio), Great Britain (London, Chatham), as well as in the USA and Japan. For the first time, the army's health care received an official status and recognition, thanks to the joint activities of reformers from different countries of the world N.I. Pirogov, L.A. Beckers, E. Chadwick, N. Arnott S. Smith, W. Farr, Lord Herbert, F. Nightingale, L. Richards, E. Parks. The transformation of public health took place on the territory of military hospitals located in the Ottoman Empire and Crimea. It is shown that, having become an integral element of the international politics of the countries of the world, during the Crimean War, public health and nursing were separated from clinical medicine, becoming a new area of state medical care.

Keywords: Crimean War, Russian Empire, Ottoman Empire, Great Britain, public health, corruption, hospital, museum, S. Gerbert, E. Chadwick, N. Pirogov, F. Nightingale.

\section{[Е.К. Склярова, О.Н. Камалова Крымская война: медикосоциальные особенности и послед- ствия]}

Рассматриваются медикосоциальные особенности и последствия Крымской войны (1853 - 1856 гг.). На основе историко-генетического метода исследования, анализируется процесс создания системы здравоохранения армии, проблемы коррупции в контексте истории Великобритании, Османской и Российской империй в середине XIX в. В годы Крымской войны общественное здравоохранение, подготовка медицинских сестёр, здравоохранение армии стали новой соерой медицины. Следствием Крымской войны стало становление женской медицинской деятельности, организация государственного ухода за ранеными, преодоление коррупции в армии, которые осуществлялись в госпиталях Крыма (в Севастополе, Бахчисарае, Карасу-Базаре, Козлове, Симферополе), в госпиталях Турции (в Скутари, Ренкио), Великобритании (Лондоне, Чатеме), а также в США и Японии. Здравоохранение армии впервые получило официальный статус и признание, благодаря совместной деятельности реформаторов различных стран мира - Н. И. Пирогова, Л.А. Беккерса, Э. Чедвика, Н. Арнотта С. Смита, У. Фарра, лорда Герберта, Ф. Найтингейл, Л. Ричардс, Э. Паркса. Трансформация общественного здравоохранения проходила на территории военных госпиталей, расположенных в Османской империи и Крыму. Показано, что, став составным элементом международной политики стран мира, в годы Крымской войны общественное здравоохранение и сестринское дело отделились от клинической медицины, став новой сферой государственной медицинской помощи.

Ключевые слова: Крымская война, Российская империя, Османская империя, Великобритания, общественное здравоохранение, коррупция, госпиталь, музей, С. Герберт, Э. Чедвик, Н.И. Пирогов, Ф. Найтингейл.

Elena K. Sklyarova - Ph.D. in History, Associate Professor, Rostov State Medical University, Rostov-on-Don, Russian Federation.

Olga N. Kamalova - Ph.D. in Philosophy, Associate Professor, Rostov State Medical University, Rostov-onDon, Russian Federation.

Склярова Елена Константиновна - кандидат исторических наук, доцент, Ростовский государственный медицинский университет, г. Ростов-на-Дону, Российская Федерация.

Камалова Ольга Николаевна - кандидат философских наук, доцент, Ростовский государственный медицинский университет, г. Ростов-на-Дону, Российская Федерация. 
The Crimean War (1853-1856), its medical and social features and consequences indicated new directions of the domestic and foreign policy of the Black Sea countries, Russia and Great Britain. However, interdisciplinary research that comprehensively compares these processes is still insufficient. Reforming public health as part of the social and foreign policy of the Black Sea countries, the Russian Empire, and the United Kingdom is the object of scientific discussions between historians and politicians, representatives of medicine and health care. The relevance of the study of medical and social characteristics and consequences of the Crimean War, the problem of corruption in the army is due to the scientific, practical and political significance of the topic. Evaluations of the ideas of N.I. Pirogov, E. Chadwick, N. Arnott S. Smith, Lord Herbert, F. Nightingale, L. Richards, E. Parks, W. Farr, L.A. Beckers, as the founders of the public health system, the institution of sisterhood, and the army's health care were not considered comprehensively.

In the works of Russian scientists, the problems of the Crimean War and public health are considered in the context of "women's charity" [12, p. 61]. In the context of the study of the Crimean War, "various assessments of the founders of the female system of caring for the wounded on the battlefields remain" [11, p. 1106]. Some of the studies consider this problem as part of the "Victorian culture" [20, p. 15]. There are studies where it is noted that "during the Crimean War, socio-medical reforms, public health and the problem of corruption became the focus of attention of social reformers, parliament, periodicals" $[19$, p. 27]. The use of an interdisciplinary approach makes it possible to expand modern assessments of the features of this war in the context of the history of the countries of the world, museology, the history of military medicine, culture, "health of the nation" [5].

The Crimean War (1853-1856) occupies a special place in the history of many countries. It went down in the history of the Black Sea region, the Ottoman Empire, the Russian Empire, Great Britain, as a military conflict, as well as the period of reforming the work of military hospitals, the formation of the institution of women's care for the wounded. Epidemics (typhus, cholera, smallpox) of the middle of the $19^{\text {th }}$ century, new trends in the development of public health have led to the adjustment of the work of military hospitals, hospitals, and the army's support system. During the war years, the control of naval hospitals was imperfect. There was no ventilation, equipment for cooking, sanitation, water supply, statistics, training of military medical personnel. Unsanitary conditions, dysentery, epidemics (smallpox, typhus, cholera) were common in military hospitals of the British, Ottoman and Russian empires. Military hospitals were critically called "outhouse" [6, p. 206].

During this period of history, militaristic and anti-Russian sentiments grew in Great Britain, which were subjectively reflected by the Economist magazine. On the pages of the publication, it was emphasized that: "we hope to take Sevastopol, revolutionize Georgia." At the same time, the editors of the magazine suggested that after these acts of expansion, Britain intends to give "Russia an equivalent equivalent of everything that we will conquer from her, and in the event of a peace agreement, we will make her a gift in the person of Mr. Chadwick" [21]. This historical period coincided with the reign of Queen Victoria, Nicholas I, Alexander II, as well as the activities of prominent politicians and representatives of medicine from Russia and Great Britain N.I. Pirogov, E. Chadwick, Lord S. Herbert, F. Nightingale. During this period, the foundations of social policy and health care of the countries of the world were being developed, including the "reform of the army and navy" [3, p. 14].

On the eve of the Crimean War, under the first "Public Health Promotion Act, 1848" in the United Kingdom in the era of Queen Victoria, for the first time "public health" was separated from clinical medicine, becoming a new field of health care [14]. This was the result of the work of parliamentary commissions, the "Association of Cities Health", a reflection of the ideas of E. Chadwick, N. Arnott, S. Smith, J. Keyay [9, p. 39]. The founder of the public health system, Edwin Chadwick, played a significant role in the development of this law. 
However, it was him who, due to corruption, was removed from activities by members of the British Parliament during the Crimean War "for criticizing the use of commercial objects that harm the health of the nation" [8, p. 1625]. But the result of the activities of this outstanding reformer was the transformation of the views of the British state on the role of health care. He was personally acquainted with the prominent figures of the Victorian era W. Farr, F. Nightingale, N. Arnott, S. Smith. During the Crimean War, Florence Nightingale, developing the sanitary and hygienic ideas of these doctors and E. Chadwick, on her own initiative worked in the Black Sea region, "helping the wounded and sick soldiers in military hospitals in Britain located in the Ottoman Empire [10, p. 164].

During the war years, the problem of the spread of massive epidemics caused by the unsanitary conditions of military conditions and hospitals became more acute. F. Nightingale carefully studied the features of public health, charity, the spread of epidemics in Britain, comparing them with the corresponding military conditions of the armies of the Ottoman and Russian empires, as well as the peaceful development of hospitals in Germany, Italy, Greece, Egypt. The novelty of her ideas consisted in the introduction of a system of professional training for military medical personnel, medical statistics, an institute of women's medical care for the wounded and sick, in solving the problems of equipping hospitals with water supply systems, cooking, cleaning and ventilation, monitoring naval hospitals to reduce mortality in army from injuries and diseases [16].

The public health reform during the Crimean War acquired new features of charitable and social assistance, becoming an important part of the domestic and foreign policy of the Black Sea countries, Great Britain, and the Russian Empire. F. Nightingale has achieved the equipping of military hospitals and hospitals with new ventilation systems, water supply, the introduction of medical statistics with the help of the Minister of War Lord Herbert. "She met him in Italy long before the Crimean War. Lord Sydney Herbert was Minister of War for the Kingdom from 1845 to 1846 and during the Crimean War. "His mother Ekaterina Vorontsova was a Russian countess, the daughter of the Ambassador of the Russian Empire to Great Britain, Count S.R. Vorontsov - general, holder of all Russian orders was an Anglomaniac and a Russian diplomat. "For half a century, Count S.R. Vorontsov lived in London. His daughter Catherine "became the wife of Count J. Herbert, and also the mother of the future Minister of War of England Sydney Herbert. It should also be noted that the Alupka Palace in Crimea belonged to the rich Vorontsov family" [10, p. 165].

In the middle of the 19th century, the problems of military operations in the Crimea were discussed in the British Parliament. It was proposed to introduce control of the medical department of the armies located in the Crimea and Constantinople, since "the losses of the British army only in September 1855 were significant ... fever, diarrhea ... dysentery in a short time led to the death of more than a thousand people in military hospitals located in the Crimea" [15].

The "Royal Army Health Commission" was created on the initiative of Parliament, Secretary of War Lord Herbert, Sister of Mercy F. Nightingale to solve the problems of providing the British army in Crimea. S. Herbert was responsible for sending the sisters of mercy to the war zone during the Crimean War. In the Scutari hospital in Turkey, thanks to the dynamic activities of F. Nightingale and the nurses, a procedure for feeding the sick and wounded, cleaning the premises of military hospitals, teaching the basics of medicine to junior personnel was introduced. The new hospital in Renkio was organized by an experienced hygienist, a graduate of the University of London, a member of the Royal Society of Surgeons E. Parks to ease the burden on the hospital in Scutari. Dr. E. Parks developed sanitary standards for the organization of hospitals and the army. The Sisters of Mercy under his leadership in Renkio took care of the sick and wounded [18, p. 441]. As a result of the reforms, the level of morbidity, mortality and unsanitary conditions in military hospitals dropped sharply. 
Lord Sidney Herbert and Florence led the movement to implement the health reform of the army, the military department after the Crimean War. F. Nightingale's activities have received national and international recognition. She developed a hospital and hospital reform plan that was presented to Queen Victoria. Florence was elected a Fellow of the Royal Statistical Society and developed the foundations for the statistical reporting of military hospitals. This idea was realized with the active assistance of the famous statistician, Dr. William Farr, and then was approved by the decision of the "International Congress of Statisticians".

After the end of the Crimean War, Lord S. Herbert and E. Parks set about creating the Military Medical School in Chetem, where the Department of Hygiene was first created. During the Victorian era, the school was reorganized into the Royal Victoria Hospital. Prince Albert and Queen Victoria personally visited the wounded soldiers who participated in the Crimean War at Brompton Hospital in Chetem. By order of the Minister of War S. Herbert, on November 1, 1865, the Royal Hospital was opened in London for wounded soldiers and veterans of the Crimean War. Jane Shaw Stewart was appointed Chief Executive Officer of nurses and learned the basics of medical care in the army while working with F. Nightingale in Crimea. In the 1860s. the field of medical activity included "nursing", which was officially approved by the International Committee of the Red Cross. Thanks to this organization, the Florence Nightingale medal has become an honorary international award for sisters of mercy of the countries of the world: "For true mercy and care for people, which arouse the admiration of all mankind" [12, p. 109].

For her charitable work during the war years, Florence was awarded the Royal Red Cross, receiving gratitude from the government of the country. The financial reward was used to organize the first Nursing School in London at St Thomas's Hospital. In the twentieth century. the school became part of King's College London. New schools of sisters of mercy were created at hospitals in Liverpool, cities in the USA, Sweden. Linda Richards, the first US nurse who received the appropriate medical education, underwent an internship at St. She developed a program for nursing schools, training the system of women's care in hospitals in the USA, Japan [17, p. 37]. New medical schools in Europe and the United States were not religious, but scientific and practical in nature, where the teaching of medicine was led by nurses.

In the post-war period, the recognition of the social activities of the participants in the Crimean War led to the creation of a memorial complex of the Crimean Guard in London. The monument to the heroes of the Crimean War was erected in front of the Waterloo Palace thanks to the sculptor J. Bell. It consists of bronze figures of the British military who took part in the battle for Sevastopol. Monuments to Minister of War Lord S. Herbert and F. Nightingale were later erected in memory of the Crimean War in the twentieth century. The memorial complex is located in Waterloo Place at the junction of Lower Regent and Pel Mel Streets. The monument to Lord Herbert is made of black bronze by the Irish sculptor J. G. Foley. And the sculpture of Florence was made by A.J. Walkcore. The English composition became a monument to the Crimean War, the women's care system for the wounded in Crimea. In the hospital of St. Thomas in London and in Istanbul (where the barracks of military hospitals were located) F. Nightingale museums were created, becoming part of the history of the Crimean War, "a socio-cultural phenomenon of the Victorian era" [2, p. 88]. The Florence Nightingale Museum "reflects the establishment of the sisterhood institution, the activities of the International Federation of Red Cross and Red Crescent Societies, the history of the development of medical clothing, bioethics, and the history of the Crimean War" [4, p. 45].

In the Russian Empire during the Crimean War, thanks to the joint activities of the Russian surgeon N.I. Pirogov, a new system of women's care for the sick and wounded was also organized. The doctor convinced Emperor Alexander II that the women of Russia 
"with their care will help the wounded to endure suffering more easily, and their independent official position would be better moral control than any commission" [7, p. 197]. At the height of the Crimean War in 1854, 35 Russian sisters of mercy were sent to a military hospital in Sevastopol. The new system of women's care for the sick and wounded carried out its activities on the battlefields in the same way as in England, thanks to the financial support of the Ministry of War, and then in St. Petersburg with the support of the Russian Red Cross Society. With the assistance of the chief physician of Sevastopol N.I. Pirogov, "thunderstorms of hospital riots" during the Crimean War at the state level began to solve the problem of "embezzlement of the quartermaster services", overcoming the "abomination of hospital management" [6, p. 200, 203]. New positions appeared - "pharmacist", "mistress-sister". The most fearless women performed dressings, assisted in limb amputations [7, p. 111-116]. All this became part of the history of Crimea, the era of the Great Reforms of Alexander II.

During the war, the historical buildings of Crimea were destroyed and covered in blood. Russian military hospitals were organized in Bakhchisarai, Karasu-Bazar, Simferopol, Sevastopol. "Aleksandrovskie barracks" became a dressing station. For hospitals used the Engineering House, the building of the Noble Assembly, the houses of Orlovsky and Gushchin [7, p. 112 - 132]. The main hall of the Nobility Assembly in Sevastopol, used before the Crimean War for holding points, became a military hospital during the war. Gushchin's house had a negative reputation, which was due to the fact that the hopeless wounded and sick were brought there. "When the order "to Gushchin" was distributed at the dressing station, the wounded cried" [13, p. 212].

In military hospitals, students of N.I. Pirogova, doctors of the Second Military Land Hospital of St. Petersburg - L.A. Beckers, C.F. Pabo, A. Reber, V.S. Sokhranichev, V.I. Tarasov, A. Tyurin, P.A. Khlebnikov. Ludwig Andreevich Bekkers, a Russian surgeon, professor of the Imperial Medical and Surgical Academy, after graduating from the medical faculty of Moscow State University, entered the military medical service, was seconded to the Second Military Land Hospital. N.I. Pirogov took him as his assistant to Sevastopol. Ludwig Bekkers also worked in the hospitals of Bakhchisarai, Kozlov, was a member of the Aleksandrovsky committee for the care of the wounded, chaired by Prince V. A. Dolgorukov, was invited by Prince $\mathrm{V}$. Vasilchikov to the commission of inquiry to uncover abuse in hospitals during the Crimean War [1, p. 349].

Thus, during the Crimean War, public health, training of nurses, and army health care became a new field of medicine. The consequence of the Crimean War was the formation of women's medical activities, the organization of state care for the wounded, the elimination of corruption in the army, which were carried out in the hospitals of the Crimea (in Sevastopol, Bakhchisarai, Karasu-Bazar, Kozlov, Simferopol), in the hospitals of Turkey (in Scutari, Renkio), Great Britain (London, Chatham), as well as in the USA and Japan. For the first time, the army's health care received official status and recognition thanks to the joint activities of reformers from different countries of the world - N.I. Pirogov, L.A. Beckers, E. Chadwick, N. Arnott, S. Smith, W. Farr, Lord Herbert, F. Nightingale, L. Richards, E. Parks. The transformation of public health took place on the territory of military hospitals located in the Ottoman Empire and Crimea. Having become an integral part of the international politics of the countries of the world, during the Crimean War, public health and nursing were separated from clinical medicine, becoming a new area of state medical care.

\section{Лumepamypa}

1. Беккерс Людвиг Андреевич // Энциклопедический словарь. СПб.: БрокгаузЕфрон, 1891.T. III. С. 349. 
2. Волкова Д.В., Склярова Е.К., Топчий И.В. Музеи Великобритании как социокультурный феномен викторианской эпохи // Гуманитарные и социальноэкономические науки. 2019. № 3 (106). С. 88.

3. Гутиева М.А., Склярова Е.К. Сравнительный анализ социальных реформ России и Великобритании в первой половине XIX века. Гуманитарные и социальные науки. 2015. № 1. С. 19.

4. Камалова О.Н., Склярова Е.К. Историко-медицинские экспонаты и музеи Великобритании // Медицинский музей и медицинская коммуникация. Сборник материалов IV Всероссийской научно-практической конференции "Медицинские музеи России: состояние и перспективы развития". Московский государственный медико-стоматологический университет имени А.И. Евдокимова. 2017. С. 45.

5. Камалова О.Н. Эстетическое освоение действительности в контексте фрилософских идей Шеллинга // Гуманитарные и социально-экономические науки. 2008. № 1 (38). С. 67-69.

6. Киселёв А.С. Николай Пирогов. Страницы жизни великого хирурга. М.: АСТ, 2018. C. $200-206$.

7. Пирогов Н.И. Севастопольские письма и воспоминания. М.: Изд-во Академии наук СССР, 1950. 111 - 116, 197.

8. Склярова Е.К., Сидоренко Ю.А., Сафрроненко А.В., Бутова Е.Н. Эволюция общественного здравоохранения в годы Крымской войны // Былые годы. Российский исторический журнал. 2019. № 54 (4). С. 1625.

9. Склярова Е.К., Котова Т.А. Эдвин Чедвик - создатель системы общественного здравоохранения. Подарок России или Великобритании. Ростов н/Д: ИПО ПИ ЮФУ, 2010. С. 39.

10. Склярова Е.К., Переверзева Д.О., Камалова О.Н. Флоренс Найтингейл и лорд Герберт в годы Крымской войны // Медики - герои войн и локальных конфликтов Материалы Всероссийской научно-практической конференции с международным участием. Ростов-на-Дону: Ростовский государственный медицинский университет, 2017. С. $164-165$.

11. Становление системы общественного здравоохранения Российской империи и Великобритании в XIX - начале XX вв. // Склярова Е.К., Гутиева М.А., Камалова О.Н., Засеева Л.Т. // Былые годы. Российский исторический журнал. 2019. T. 3. № 53. C.1106.

12. Харламов Е.В., Склярова Е.К., Киселёва О.Ф. Милосердие как призвание. Ростов-на-Дону: Мини Тайп, 2017. С. 61, 109.

13. Чверткин Е.И. Незабытый Севастополь. Севастополь: Телескоп, 2008. С. 212.

14. An Act for promoting the Public Health (1848) // 11 \&12 Vict. c. 63. P. $721-784$.

15. Hansard Parliamentary Debates. 3-rd Series. 1855. Vol. 139. P. $954-1018$.

16. Nightingale F. Notes on Nursing: What It Is and What It Is Not. - L.: Wilder Publications, 2007. - $116 \mathrm{p}$.

17. Reminiscences of Linda Richards America`s first trained nurse. Boston: Whitcomb \& Barrow, 1915.P. 37.

18. Shepherd J. A. The Crimean Doctors: a History of the British Medical Services in the Crimean War. Liverpool: Liverpool University Press, 1991. Vol. 1. P. 441.

19. Sklyarova E.K Crimean war and establishing of public health system in Great Britain. Научный альманах стран Причерноморья. 2017. № 1 (9). С. 25.

20. Swenson K. Medical Women and Victorian Fiction. Missouri, L.: University of Missouri Press, 2005. P.15.

21. The Economist. 1854. Aug. 5. 


\section{References}

1. Bekkers Lyudvig Andreyevich. Entsiklopedicheskiy slovar [Bekkers Ludwig Andreevich. Encyclopedic Dictionary.]. Saint Petersburg: Brokgauz-Yefron, 1891. V. III. 349 p. (in Russian).

2. Volkova D.V., Sklyarova Ye.K., Topchiy I.V. Muzei Velikobritanii kak sotsiokulturnyy fenomen viktorianskoy epokhi [Museums of Great Britain as a socio-cultural phenomenon of the Victorian era]. Gumanitarnyye i sotsialno-ekonomicheskiye nauki. 2019. No. 3 (106). 88 p. (in Russian).

3. Gutieva M.A., Sklyarova E.K. Sravnitelnyi analiz sotsialnykh reform Rossii i Velikobritanii v pervoi polovine XIX veka [The comparative analysis of social reforms of Russia and Great Britain in the first half of the 19th century]. Gumanitarnyye i sotsialno-ekonomicheskiye nauki. 2015. No. 1. 19 p. (in Russian).

4. Kamalova O.N., Sklyarova E.K. Istoriko-meditsinskie eksponaty i muzei Velikobritanii. Meditsinskii muzei i meditsinskaia kommunikatsiia Sbornik materialov IV Vserossiiskoi nauchno-prakticheskoi konferentsii "Meditsinskie muzei Rossii: sostoianie i perspektivy razvitiia" [Historical and medical exhibits and museums of Great Britain. Medical museum and medical communication. Collection of materials of the fourth All-Russian scientific and practical conference "Medical museums of Russia: condition and prospects of development"] A.I. Yevdokimov Moscow State University of Medicine and Dentistry. 2017. 45 p. (in Russian).

5. Kamalova O.N. Esteticheskoye osvoyeniye deystvitel'nosti v kontekste filo-sofskikh idey Shellinga [Aesthetic assimilation of reality in the context of Schelling's philosophical ideas]. Gumanitarnyye i sotsial'no-ekonomicheskiye nauki. 2008. No.1 (38). pp. 67-69 (in Russian).

6. Kiselov A.S. Nikolay Pirogov. Stranitsy zhizni velikogo khirurga [Nikolay Pirogov. Pages of the life of the great surgeon]. Moscow: AST, 2018. pp. 200-206 (in Russian).

7. Pirogov N.I. Sevastopolskiye pisma i vospominaniya [Sevastopol letters and memoirs]. Moscow: Izdatelstvo Akademii nauk SSSR, 1950. pp. 111-116, 197 (in Russian).

8. Sklyarova E.K., Sidorenko Yu.A., Safronenko A.V., Butova E.N. Evolyutsiya obshchestvennogo zdravookhraneniya $v$ gody Krymskoy voyny [Evolution of public health care during the Crimean War]. Bylyye gody. Rossiyskiy istoricheskiy zhurnal. 2019. No. 54 (4). 1625 p. (in Russian).

9. Sklyarova E.K., Kotova T.A. Edvin Chedvik - sozdatel sistemy obshchestvennogo zdravookhraneniya. Podarok Rossii ili Velikobritanii [Edwin Chadwick is the creator of the public health system. Gift from Russia or Great Britain]. Rostov-na-Donu: IPO PI YUFU, 2010. 39 p. (in Russian).

10. Sklyarova E.K., Pereverzeva D.O., Kamalova O.N. Florens Naitingeil i lord Gerbert v gody Krymskoi voiny. Mediki - geroi voin i lokal'nykh konfliktov. [Florence Nightingale and the lord Herbert in the years of the Crimean War. Physicians are heroes of wars and local conflicts. Materials of the All-Russian scientific and practical conference with the international participation.] Rostov-on-Don. 2017. 163 p. (in Russian).

11. Stanovleniye sistemy obshchestvennogo zdravookhraneniya Rossiyskoy imperii i Velikobritanii $\mathrm{V}$ XIX - nachale XX vv. [Formation of the public health system of the Russian Empire and Great Britain in the 19th - early 20th centuries]. Sklyarova Ye.K., Gutiyeva M.A., Kamalova O.N., Zaseyeva L.T. Bylyye gody. Rossiyskiy istoricheskiy zhurnal. 2019. V. 3. No. 53. 1106 p. (in Russian).

12. Kharlamov E.V., Sklyarova E.K., Kiseleva O.F. Miloserdie kak prizvanie. [Mercy as a calling.] 2017. 108 p. (in Russian). 
13. Chvertkin Ye.I. Nezabytyy Sevastopol [Unforgotten Sevastopol]. Sevastopol: Teleskop, 2008. 212 p. (in Russian).

14. An Act for promoting the Public Health (1848). 11 \&12 Vict. p. 63. pp. 721-784.

15. Hansard Parliamentary Debates. 3-rd Series. 1855. Vol. 139. pp. 954-1018.

16. Nightingale F. Notes on Nursing: What It Is and What It Is Not. London: Wilder Publications, 2007. $116 \mathrm{p}$.

17. Reminiscences of Linda Richards America`s first trained nurse. Boston: Whitcomb \& Barrow. 1915. 37 p.

18. Shepherd J.A. The Crimean Doctors: A History of the British Medical Services in the Crimean War. Liverpool: Liverpool University Press, 1991. V. 1. 441 p.

19. Sklyarova E.K. Crimean war and establishing of public health system in Great Britain. Scientific almanac of the Black Sea countries. 2017. No. 1 (9). 25 p.

20. Swenson K. Medical Women and Victorian Fiction. Missouri, L.: University of Missouri Press, 2005. $15 \mathrm{p}$.

21. The Economist. 1854. Aug. 5. 